\title{
'RAÇA', ETNICIDADE E SAÚDE REPRODUTIVA: O CASO AFRO-LATINO-AMERICANO
}

\author{
Livio Sansone
}

Já é possível assumir que a vivência de questões relacionadas à saúde reprodutiva e ao tipo e à qualidade dos direitos sobre a saúde reprodutiva é fortemente influenciada pela 'raça', origem étnica e/ou classe social. Sabemos, ademais, que etnicidade, racialização, gênero e sexualidade estão relacionados. Por outro lado, a forma pela qual esta conexão funciona no dia-a-dia ainda continua bastante inexplorada e, o mais importante, pouquíssimas intervenções se concentram nesta interconectividade.

Neste texto, primeiro, esboço esta interconectividade em vários países e regiões que foram estrategicamente selecionados, porque cada um representa de maneira específica uma situação de tensão particular, que frustra muitas das regularidades da intervenção social e da pesquisa. ${ }^{1}$ São regiões que apresentam tensões extremas e também antecipam o que pode acontecer no resto da América Latina, pois são simplesmente regiões que foram mais intensamente expostas à globalização. ${ }^{2} \mathrm{O}$ Brasil continuará a ser o meu referencial, a lente através da qual tentei observar outros lugares.

A condição étnico-racial, a condição de classe baixa e a condição de juventude foram visadas em todos os lugares visitados, e definem o contexto mais

\footnotetext{
1 Este texto é o resultado de uma pesquisa exploratória em forma de consultoria para o escritório da Fundação Ford do Rio de Janeiro. A pesquisa foi realizada durante um mês, em 2000, com o objetivo de sugerir direcionamentos para novos terrenos e abordagens no campo da saúde reprodutiva, através de uma nova leitura das questôes da saúde reprodutiva, tendo-se em mente novas formas de identidade étnica dos jovens de classes baixas em vários países latinoamericanos. Apesar de se concentrar na população de descendência africana, ele também contém referências à revivescência étnica entre os jovens das populações indígenas nativas.

2 Trata-se, ademais, de países de interesse dos três escritórios da Fundação Ford na América Latina - Rio de Janeiro, Cidade do México e Santiago.
} 
amplo da saúde reprodutiva. Jovens de classe baixa de origem africana ou indígena, apesar de não necessariamente se encontrarem sempre na posição de vítimas, parecem formar um grupo central na exposição das falhas na prática geral, aberta e livre dos direitos sobre a saúde reprodutiva.

Depois de esboçar os métodos, detalho como as populações de origem negra ou indígena e as suas identidades étnicas foram conceituadas na América Latina. A seguir, descrevo o contexto das tensões étnicas nos lugares visitados, tentando mostrar como algumas novas dinâmicas em torno da identidade étnica ressaltam mudanças profundas no contexto dentro do qual se vivencia a saúde reprodutiva e se reclama o direito a esta saúde. A seção final aborda os fatores fundamentais que caracterizam a mudança na vivência da sexualidade, saúde reprodutiva e identidade étnica.

Tive apenas três semanas para visitar os três países. É claro, precisei aproveitar este tempo da melhor maneira possível: fazendo contato com organizações políticas, ONGs, estudiosos do meio acadêmico e (possíveis) donatários, mas também explorando várias regiōes com um histórico diferente da situação brasileira em termos de conflitos étnicos e intervenção no campo de direitos étnico-humanos. Dividi o meu tempo entre capitais nacionais (Cidade do México, Manágua e Bogotá) e cidades e regiões específicas. Nas primeiras, entrevistei pessoas em órgãos governamentais, entidades coordenadoras de ONGs e organizações nacionais de minorias étnicas. As últimas foram escolhidas para a obtenção das primeiras impressões sobre os problemas sociais em questão. As informações foram coletadas através de uma variedade de métodos: questionários abertos, conversas mais informais, discussões em grupo, relação de documentos escritos e estatísticas, e uma boa dose de observações participativas intensivas, porém curtas, visitando comunidades e projetos.

\section{O mapeamento da população afro-latina e o 'problema étnico'}

A determinação do tamanho e da composição sociodemográfica de uma população específica é importante ao se adotarem medidas voltadas para necessidades específicas desta população. No caso das pessoas de descendência africana na América Latina, isto é um grande problema. Dos quatro países considerados por este trabalho, apenas o Brasil coleta sistematicamente dados sobre 'cor' e 'raça' no censo nacional e em alguns levantamentos de grande escala de amostras realizados em todo o país - Pesquisa Nacional por Amostra de Domicílios (Pnad) e Pesquisa de Emprego e Desemprego (PED). 
O censo mexicano conta o número de pessoas capazes de falar um idioma indígena; a Colômbia possui apenas estimativas da população total de negros e mulatos, apesar de, nos últimos anos em várias regiões, pesquisas e projeções demográficas mais cuidadosas terem começado a ser realizadas; o censo da Nicarágua pede que as pessoas nas duas regiōes da Costa Atlântica se identifiquem entre os grupos étnicos oficialmente reconhecidos (mestizo, creole, miskito, garifuna e sumo-mayagna); no Brasil, o entrevistador pede que as pessoas selecionem um único termo entre os três oficiais para a cor (preto, pardo e branco) e os dois termos de cunho etno-cultural (indígena e amarelo).

Os métodos através dos quais os dados são coletados não apenas recebem críticas muito freqüentemente a partir de pontos de vista diferentes - líderes étnicos, pesquisadores sociais, líderes religiosos, políticos e imprensa popular - como também mostram-se muito difíceis de serem comparados internacionalmente. O que é negro na Nicarágua pode ser algo diferente na Colômbia; o que é pardo no Brasil pode ser creole na Nicarágua. No Brasil, no México e na Colômbia, vários pesquisadores disseram que o sistema de classificação racial é muito mais complexo do que o retratado nas estatísticas oficiais. Termos raciais e étnicos geralmente são usados de acordo com a situação; a mesma pessoa pode ter, segundo o lugar, cores diferentes.

A fluidez na terminologia racial e étnica, que é típica da América Latina e também de outras partes do mundo com uma incidência de casamentos interraciais (mestiçagem), é claro, não significa que esta terminologia não esteja refletindo hierarquia e domínio. Para os fins deste artigo, é útil, de qualquer maneira, dar uma visão geral do número de pessoas de descendência africana nos países latino-americanos - levando-se em consideração que reportamos a estimativas que resultam de várias perspectivas ou dados que são coletados de acordo com métodos diferentes (ver Whitten \& Torres, 1995). As cifras produzidas por ativistas negros tendem a ser (muito) mais altas que as das estatísticas. 3

Dois comentários básicos devem ser feitos aqui. Primeiro, ser 'negro' não corresponde à mesma posição social em todas as sociedades - mesmo que na maioria das sociedades os traços negróides tendam a se concentrar nas classes mais baixas. Os negros nem sempre são os menos favorecidos nem os perdedo-

\footnotetext{
3 O tamanho das populaçôes definidas como negras varia muito na América Latina. Comparando estimativas produzidas por fontes diferentes, temos uma população que representa cerca de $47 \%$ no Brasil (se somamos pretos e pardos); entre 14 e $43 \%$, na Colômbia; entre 5 e $10 \%$, no Equador; entre 9 e $70 \%$, na Venezuela; entre 6 e $10 \%$, no Peru; e entre 34 e 62\%, em Cuba. Para um quadro mais geral destas estimativas para toda a região, ver Minority Rights Group (1995).
} 
res. As histórias recentes do México e da Nicarágua aparecem, neste sentido, diferentes das do Brasil e da Colômbia - onde há uma tendência na qual os negros são mais expressivamente representados entre os menos privilegiados. Segundo, a existência de pessoas com aparência fisicamente 'diferente' não resulta, necessariamente, em um problema racial ou étnico: o que configura um problema étnico é a sua projeção na história política de um país ou uma região. Em outras palavras, a identidade étnica e/ou racial é mobilizada apenas em certas circunstâncias. Ser de descendência africana, pobre e até mesmo sofrer discriminação, por si, não é o suficiente para que um negro reivindique algum tipo de identidade negra. Isto é óbvio no mundo latino-americano, onde a identidade negra tende a ser mais episódica do que um fator político e eleitoral constante.

É claro, a negritude e a brancura não são entidades determinadas, mas sim construções que podem variar em espaço e tempo, e de um contexto para o outro. O poder de definição de uma diferença étnico-racial - por exemplo, 'negritude' como o oposto de 'brancura' - depende muito do fato de que ela funciona tanto interna quanto externamente. Na verdade, na América Latina, a maioria das definições de negritude usadas pelos acadêmicos e também pelas agências da sociedade política funciona principalmente de maneira externa. $\mathrm{O}$ que é 'negro' para uma pessoa de fora não significa necessariamente a mesma coisa para uma pessoa de dentro, e vice-versa.

Em relação à fluidez e à relatividade da lógica interna de um sistema de relações raciais, estudiosos do meio acadêmico, fundações e ONGs tendem a justapor uma linguagem polarizada (negro-branco), que nem sempre leva a uma melhor compreensão das dinâmicas geralmente sutis da discriminação racial e da grande variedade de possíveis formas de resistência individual ou coletiva contra o racismo. Insisto que seria melhor usar uma abordagem menos teórica e mais prática da identidade negra - relatando todas as formas possíveis através das quais ela aparece, em vez de focalizar apenas as novas que se enquadram na nossa abordagem teórica. Nos casos seguintes, veremos o quanto as linhas étnicas e raciais em transformação podem ser diversificadas, e o quanto a identidade étnica e a racialização fazem parte de um processo geral de redefinição de identidades sociais e da posição do indivíduo na sociedade.

\section{Quatro casos: uma visão a partir do Brasil}

Durante as últimas duas décadas, chamar a atenção para a ligação entre a saúde reprodutiva e 'raça' tem sido uma das iniciativas fundamentais do movimento negro brasileiro. As iniciativas vêm se concentrando em três aspec- 
tos: esterilização seletiva e controle da natalidade de forma mais geral, violência (da polícia) e os efeitos da mestiçagem. ${ }^{4}$ Estes aspectos são entrelaçados, porque estão relacionados à questão dos números e da demografia - já que severamente limitariam o crescimento da parcela de negros na população do Brasil.

A questão da esterilização como parte de um debate mais geral sobre a saúde reprodutiva criou uma divisão entre organizações negras e brancas nos movimentos feministas (ver Pinto, 1998 e outras contribuições ao livro editado por Werneck, 2000). Em termos gerais, as feministas negras tendem a ser mais conscientes e cautelosas em relação às políticas e medidas oficiais voltadas para o controle da natalidade. Esta pluralidade de posições, insistem as vozes feministas negras, nem sempre é reconhecida nas declarações e publicações feministas mais notórias - que, ao contrário, tendem a sugerir a unidade da condição feminina. Um quarto aspecto, que diz respeito à questão mais geral da saúde, é a possibilidade de uma freqüência maior de certas doenças causadas por fatores genéticos na população negra, sendo a anemia falciforme mencionada com mais freqüência.

Sem questionar a centralidade de todos estes aspectos, que de fato têm uma importância em termos da composição futura da população negra, e sem querer discutir detalhadamente aqui as suas interpretações controvertidas - que vão desde um plano centralizado para exterminar a seção mais escura da população até explicações que enfatizam questões sociais e não raciais -, gostaria de chamar a atenção para a escassez de pesquisas e de ações relacionadas a um número de fatores fundamentais da saúde reprodutiva com conseqüências importantes para a composição demográfica da população negra, como também para a vida cotidiana. Por exemplo, 1) a construção da brancura e da negritude; 2 ) a possibilidade que existam formas de estrutura familiar específicas da população negra; 3) a forma pela qual a 'raça' afeta as relações de gênero, sexualidade e padrões de casamento entre os jovens; 4) o desenvolvimento do chamado grupo de homens em condições de casamento - a 'cesta dos parceiros'; 5) as práticas e as políticas em torno da produção e reconstrução do corpo - plástica, manipulação do cabelo (negro), uso de hormônio e medicamento para emagrecer etc.

\footnotetext{
4 Tradicionalmente, dentro do ativismo negro no Brasil e em outros países, há vozes que definem a mestiçagem como uma estratégia consciente para aniquilar a raça negra, como parte de medidas racistas e malthusianas (Nascimento, 1978).
} 
Estes temas não têm recebido muita atenção, apesar de serem essenciais em outros países com grandes populações negras, de penetrarem a mídia e a opinião pública, e de terem sido debatidos com freqüência no Brasil no passado. ${ }^{5}$ Ou seja, no Brasil, até agora, no trabalho de ativistas negros e pesquisadores, a conexão entre saúde reprodutiva e condição racial vem sendo buscada em um nível relativamente alto de abstração, ao mesmo tempo em que não se tenta fazer isto em um nível que a tornaria mais perceptível para a grande maioria da população.

Nas três seções seguintes, veremos como a ligação entre saúde reprodutiva, sexualidade, 'raça' e etnicidade é percebida nos lugares que visitei.

\section{México}

Em princípio, minha pesquisa tinha o objetivo de tratar apenas das populações de descendência africana. Quanto a isto, tinha decidido que enfocaria três países: o Brasil, mais os dois países com a maior população negra estimada na população nacional total, a ser encontrada na área de intervenção de dois escritórios regionais da Fundação Ford na Cidade do México (América Central) e em Santiago (América do Sul de língua espanhola). Estes dois países eram a Nicarágua e a Colômbia - sobre os quais tinha tentado ler, mas que sempre desejara conhecer melhor. No entanto, percebi que seria uma pena não incluir o México neste esforço comparativo. Afinal, o México é a segunda maior economia na América Latina e, no campo da sociologia e da antropolo-

\footnotetext{
5 A 'origem' de várias estruturações familiares encontradas com freqüência em comunidades negras de classe baixa no Novo Mundo (principalmente, a incidência relativamente alta de lares onde o provedor é uma mulher), seja como resultado de uma tradição africana ou da ruptura que veio com a escravidão, encontrava-se na fonte de uma famosa questão polêmica entre Franklin Frazier e Melville Herskovits. Os dois discutiam com base em um estudo de campo realizado em Salvador, Bahia, nos anos 1940-1942 (Frazier, 1942; Herskovits, 1943). Nos Estados Unidos e em outros países, o debate sobre a possível existência de formas específicas de 'famílias negras' na maioria das vezes tem ocorrido dentro da estrutura e da cultura do Estado da Previdência Social (ou o que sobrou dele), e tem acompanhado a naturalização e racialização da mãe solteira, do pai que aprende sobre a vida na rua e da gravidez da adolescente. No Brasil e na América Latina em geral, possivelmente devido à falta de intervenção do Estado na pobreza e à ausência de um sistema previdenciário articulado, este processo de estigmatização da população negra como 'pobres não merecedores' não tem ocorrido tanto. Esta diferença em relação a países com um (passado de) sistema de Previdência Social deve ser levada em consideração ao se fazer uma comparação internacional.
} 
gia, vem mantendo contatos relativamente freqüentes com o Brasil - embora este intercâmbio tenha diminuído durante a última década. 6 Acima de tudo, há outras boas razões para a comparação com o Brasil, como a proximidade do México dos Estados Unidos, a variedade étnica, a tradição de uma presença relativamente forte do Estado na administração de tensões e identidades étnicas, uma forte tradição em termos de pesquisa das relações e tensões interétnicas (os estudos étnicos) e o papel central da antropologia na construção de um discurso nacional sobre 'raça' e mexicanidad (dois marcos neste processo são o Museu Nacional de Antropologia e o Museu de Cultura Popular).

O México poderia ter sido incorporado ao projeto enfocando-se a sua tercera raiz: a influência das pessoas de descendência africana na história, cultura e 'raça' mexicanas - sendo a primeira raiz, a indígena nativa, e a segunda, a ibérica. Isto é bastante reconhecido na pesquisa histórica (Beltran 1956). Uma pesquisa minuciosa também detectaria uma variedade interessante de mestiçagens e de relações raciais nos estados de Guerrero e Vera Cruz, onde os traços físicos de descendência africana são mais facilmente percebidos em uma parte considerável da população. 7

No entanto, hoje, no México, o debate sobre etnicidade - em vez de girar em torno da aceitação de uma presença africana importante na textura da sociedade mexicana - gira em torno da questão da autonomia política e das medidas para a proteção das culturas indígenas na educação e nos serviços públicos. ${ }^{8}$ Apesar de tensões e mesmo rebeliões armadas ou guerrilhas de um tipo ou de outro serem encontradas em vários estados mexicanos, a situa-

\footnotetext{
6 Podemos lembrar de pelo menos três exemplos de parcerias importantes entre cientistas sociais mexicanos e brasileiros em períodos diferentes do estudo sobre raça e relações interétnicas: Gilberto Freyre e Aguirre Beltran (e Vasconcelos, embora de maneira indireta), Guillermo Bonfill e Darcy Ribeiro, Roberto Cardoso de Oliveira e Rodolfo Stavenhagen (ver Bartolomé \& Barabas, 1998).

7 Durante as últimas duas ou três décadas, alguns estudiosos - sobretudo Luz María Montiel têm se dedicado a trazer à luz a contribuição africana. Estes esforços têm sido ampliados por um número de eventos especiais organizados pelo Centro de Investigaciones y Estudios Superiores en Antropología Social (Ciesas), pela organização de várias exposições (uma também foi exibida no Museu Smithsonian) e até mesmo pela abertura de um pequeno museu dedicado à tercera raiz.

$8 \mathrm{Na}$ verdade, quando sugeri a Pablo Farias que Vera Cruz fosse incluído em um possível projeto comparativo no campo de direitos humanos, etnicidade e saúde reprodutiva, ele me disse que "não precisamos inventar o 'problema' da herança africana na nossa sociedade para você incorporar o México no seu projeto. Por que não incluir a questão polêmica que tem sido enfocada no debate sobre a diversidade étnica no México: a situação em Chiapas?".
} 
ção em Chiapas durante os últimos cinco ou seis anos exige uma atenção especial. Chiapas é, por assim dizer, um importante laboratório para a definição das formas através das quais o México desenvolverá as suas futuras políticas e práticas em termos de diversidade cultural e étnica, e também em termos de incorporação de grupos socialmente marginais na economia dominante.

Chiapas é um estado bastante pequeno da federação, com cerca de 3 milhões de habitantes em 1990. É o quarto maior estado - depois de Yucatan, Oaxaca e Quintana Roo - com parcela da população considerada indígena ${ }^{9}$. Segundo o censo de 1990 , no estado de Chiapas, $26,42 \%$ da população eram indígenas, sendo, porém, mais de $80 \%$ na região que constitui a Diocese de San Cristobal de las Casas (Harvey, 2000). A percentagem de indígenas mudou de maneira um pouco estranha: de $22,12 \%$ em 1979 para $27,73 \%$ em 1980 , e $26,42 \%$ em 1990 . Esta variação ainda precisa ser explicada. Para alguns, ela estaria relacionada à taxa de natalidade - muitas vezes tida como mais baixa na população indígena do que no resto da população. Para outros, dependeria de contingências políticas em transformação que podem afetar a forma pela qual as pessoas se apresentam. Outras opiniões diriam que esta variação ainda depende da metodologia do censo. Ou um pouco de cada um destes três fatores?

É claro aqui, como em outras áreas de tensão étnica, que a contagem étnica geralmente responde a escolhas políticas. Minorias étnicas normalmente alegam representar um número (muito) maior do que as estatísticas oficiais. Também poderia se dizer que as pessoas que não são fluentes em um idioma indígena podem se considerar, e podem realmente ser vistas por outros, como sendo indígenas. 10 De fato, a rebelião zapatista e as suas conseqüências mostraram o que a mudança na identificação com o indígena nativo e na auto-identificação étnica pode fazer. A rebelião criou novas divisões e novas alianças tanto na população nacional como em Chiapas. Muitos habitantes urbanos de diferentes classes sociais simpatizavam com as exigências do Exército Zapatista de Liberação Nacional (EZLN), enquanto muitas pessoas que se consideravam indígenas simpatizavam com os clamores naciona-

\footnotetext{
9 O Censo General de la Poblacion y Vivienda considera indígenas os indivíduos com mais de cinco anos de idade que declaram fluência em um dos idiomas indígenas (Peréz Ruiz, 1994).

10 O censo das décadas de 1930 e 1940 também investigou hábitos alimentares e o uso de certas vestimentas como parte dos esforços em identificar quem poderia ser contado como indígena - nesta época, ainda mais do que hoje, definido como um status em contraste básico à 'modernidade'.
} 
listas do governo do Partido Revolucionário Institucional (PRI) e do establishment, ou simplesmente não foram capazes de se identificar com a nova e jovem liderança do EZLN.

Quando estava em Chiapas, todas as pessoas que entrevistei me disseram que a situação tinha chegado a um impasse: a negociação tinha sido paralisada tanto pelo Estado quanto pelo EZLN. A presença de um exército de 90 mil componentes estava ali para ficar até uma segunda ordem; havia também muitos grupos armados e paramilitares a serem levados à mesa de negociação; a comunidade estava dividida segundo linhas religiosas (sendo a divisão principal entre pentecostais e católicos, mas havia também divisões entre os católicos de tendências 'progressistas' e 'conservadoras'). Ou seja, a situação era extremamente complexa e qualquer análise exigiria um bom nível de sofisticação. Contei com vários estudos 11 e com minhas entrevistas - nas quais insisti na condição da juventude e na saúde reprodutiva.

O pessoal de Sná Stzibajom (Casa de Escritor Indígena) me descreveu a forma pela qual um grupo de jovens locais instruídos tinha evoluído a partir da posição de informantes para pesquisas antropológicas e lingüísticas, grupo este que muito tinha contribuído para o longo ciclo de pesquisas patrocinadas pela Universidade de Harvard e pelo Instituto Smithsonian, que durou de 1942 a 1982, e enfocava as 'tradições maias'. Estes jovens tinham se tornado agentes étnicos que se beneficiavam do status que as línguas nativas tinham conquistado através da sua reconstrução como línguas escritas feita pelos cientistas. A liderança atual da ONG é formada pelos filhos e filhas daquela geração de informantes fundamentais para os estudiosos de Harvard. Eles me contaram como, através do seu trabalho como escritores e atores, relembram e representam a humilhação e a discriminação sofridas pelos indígenas em Chiapas e na sua capital, San Cristobal. O único interesse que os indígenas despertavam nos fazendeiros e nos coletos (a classe média e a elite urbana mestiça) era como mãode-obra barata com poucos (ou nenhum) direitos.

Eles se sentem satisfeitos em contar como os coletos se chocaram com a rebelião de 1994: "Nuestros inditos y cholitos son incapazes de hacer esto!". A rebelião, com a qual estes escritores e atores tanto se identificavam, foi o resultado da convicção de que o protesto pacífico não tinha até então levado a nada; de que o desprezo e o silêncio tinham de ser rompidos. Eles argumentavam:

11 Recorri, entre outros, ao de Neil Harvey (2000) e ao número especial sobre Chiapas da revista Identities (v. 3, n. 1-2, 1996), que foi organizado por Daniel Mato. 
Algo precisava ser feito para se contrapor àquele processo de destruição dos valores da nossa cultura, pois se podia ver, e ainda se pode, que muitos jovens deixavam para trás o campo - o locus da identidade indígena mais forte -, como também a língua, os trajes típicos e a carga religiosa. Muitos jovens não vêem nada de positivo na nossa cultura e preferem migrar para os Estados Unidos - onde eventualmente podem acabar redescobrindo a sua cultura original, favorecida pelo ambiente multiétnico de lá. Muitos jovens sentem que ser indígena equivale a ser pobre e isolado. De qualquer forma, todos gostam da música ranchera que vem do norte do México, 12 como também dos imensos chapéus de estilo texano que gostam de exibir em público quanto têm dinheiro para comprá-los.

Aparentemente, é apenas no Distrito de Sinacantan, uma área relativamente rica que se beneficiou da agricultura e floricultura intensiva, que os jovens têm orgulho de usar vestimentas indígenas, que eles transformaram em um estilo em desenvolvimento - incorporando pequenas lâmpadas no caro bordado tradicional. Ou seja, modernizaram as vestimentas indígenas e elas entraram na moda. Na verdade, comenta-se que os pequenos empresários rurais de Sinacantan são um bom exemplo de como o orgulho étnico pode caminhar junto ao sucesso econômico. É interessante: os rapazes de Sinacantan são considerados um ótimo partido para moças indígenas, que, de outro modo, preferem se casar com não-indígenas, até como uma maneira de escapar tanto da pobreza como da limitação da sua privacidade imposta pela vida comunitária indígena, onde as relações são extremamente estreitas.

Também fiquei muito impressionado com aquilo que se pode chamar de 'o outro lado da frente zapatista' - a elite ou classe média mestiça ou ladina em San Cristobal de las Casas. 13 Este grupo, geralmente chamado de los coletos, tradicionalmente se vê como o oposto de tudo o que é indígena - apesar do fato de muitos deles serem de descendência mista, tendo incorporado aos pou-

\footnotetext{
12 Depois muitas pessoas me disseram que os zapatistas fazem festas de dança impressionantes que duram a noite inteira, com pouquíssima ou nenhuma bebida alcoólica, nas quais basicamente só tocam rancheras (a música do norte do México). A música indígena tradicional que comprei em uma loja especializada no centro de San Cristobal fica restrita a um número limitado de eventos e locais associados a 'tradições' ou exibições públicas, como no (bem-cuidado) Museu de Medicina Tradicional.

13 Neste sentido, é determinante o trabalho do antropólogo peruano Edgar Sulca, no Centro de Estudios México Centro América (Cesmeca).
} 
cos os indígenas e até mesmo alguns afro-mexicanos que ainda não tinham sido detectados na cidade até um século atrás.

Edgard Sulca nos conta como o indígena tem construído a sua própria imagem projetando em si mesmo o que os outros pensam sobre ele. Em San Cristobal, estes outros são muito especiais e ele decidiu estudá-los. Por isso, é muito diferente de alguns antropólogos que tendem a se concentrar nos indígenas e, geralmente, nos mais 'tradicionais' e 'isolados' entre eles. A cidade de San Cristobal é antiga e foi fundada durante o início do período colonial. Chiapas sempre foi o lugar onde o poder político e os sinais de 'modernidade' se concentravam. Sua estrutura altamente hierárquica funcionava com base em um sistema de classificação calcado no cultivo e na manifestação da 'diferença' como forma de expressar domínio. Isto era óbvio na arquitetura da casa colonial, com espaços especiais para os criollos, mestizos e índios. A passagem de uma casta para a outra era possível, mas difícil e limitada a indivíduos muito especiais.

Isto continuou sem grandes mudanças até a rebelião de 1994, que mostrou de forma bastante repentina que esta hierarquia tinha transformado a cidade no que Sulca definiu com humor como um 'parque social jurássico'. Hoje, esta impressionante polarização índio-coleto, que os últimos defenderam veementemente, tornando muito difícil a exibição pública no centro da cidade de qualquer coisa que associassem com indígena, está desmoronando. As divisões de classes estão mais óbvias do que nunca. Por um lado, há o indígena com dinheiro que decide vir e morar na cidade e, por outro, nem todos os ladinos querem continuar a ser chamados de coletos. No entanto, tanto na cidade quanto no campo, a memória social parece ser mais tenaz do que a realidade. Então, na cidade, as tensões ainda são representadas com freqüência em termos de indígenas versus coletos, e no campo, em termos de ganaderos versus indígenas.

$\mathrm{Na}$ realidade, na cidade, a maioria dos coletos teve que mudar radicalmente a sua objeção a priori em relação aos símbolos associados ao indígena, já que a maioria deles está agora envolvida, muitas vezes como empresários, na crescente indústria turística, que se alimenta da 'diferença' exótica do indígena de Chiapas - a maioria dos hotéis e restaurantes exibe símbolos e artefatos indígenas. No campo, muitos (jovens) indígenas agora estão se vestindo e se comportando como os charros (os norteños ou mesmo a representação TexMex dos cowboys) - que, para eles, é menos submissa e mais 'moderna' do que a vestimenta indígena tradicional.

Conversei com várias pessoas sobre o EZLN, os zapatistas. Afinal de contas, foi através daquelas imagens e do carisma do subcomandante Marcos, com o seu eterno capuz balaclava, que muitos de nós não-mexicanos ouvimos falar 
(ou lemos em sites da Internet) sobre Chiapas. É claro, o que é bom e romântico visto de fora pode ser mais complexo e muitas vezes ameaçador, porém muito mais interessante ao ser observado de uma distância menor. Este é um assunto muito delicado em Chiapas. A região está ocupada pelo exército, as tensões ainda são muito fortes em certas partes e mesmo os meus informantes mais críticos têm um certo grau de respeito pelo EZLN. A crítica principal que ouvi é que o EZLN, depois de tudo, não tem deixado que os indígenas se expressem diretamente, sendo eles geralmente representados por mestizos ou mesmo por estrangeiros - como ficou claro nas mesas-redondas com o governo em 1999.

A popularidade do EZLN entre certos grupos de estrangeiros estava relacionada a muitos fatores. Certamente, um fator muito importante é que parecia, afinal, que era possível vislumbrar uma revolução 'politicamente limpa e até mesmo correta'. A discreta, porém charmosa, liderança sem rosto fazia parte disto, com slogans como 'tudo para todos, nada para nós'. A contenção relativa do uso de violência é um outro fator. Pessoas de fora, no entanto, tendem a ter uma visão romântica da rebelião e a construir os rebeldes como uma imagem invertida do seu próprio estilo de vida (moderno, consumista, poluído etc.). Eu mesmo percebi em várias ocasiões que a rebelião de 1994 - como tinha sido o caso de rebeliões indígenas no passado (Harvey, 2000) - tinha mudado as fronteiras da distinção entre indígena e não-indígena, tornando possível vislumbrar o fato de ser indígena como parte de noções como 'desenvolvimento'.

No entanto, ainda há muito a fazer. A nova (freqüentemente informal) liderança indígena está muito mais consciente da 'arrogância natural' dos ladinos, que facilmente tendem a se promover como porta-vozes da causa indígena. A nova liderança também discorda de uma nova estratégia (o silêncio e o afastamento) que vem sendo usada por uma boa parte da população indígena nativa por falta de uma alternativa melhor. Em várias das conversas em grupo que tive, os indígenas costumavam ficar calados enquanto os ladinos se expressavam mais verbalmente. Não é apenas uma questão de proficiência lingüística, mas sim de um hábito étnico - o uso de uma tradição que alterna retiradas de longa duração com rebeliões repentinas.

Em se falando de jovens entre os índios, uma das coisas que mais se escuta é que o indígena se torna 'adulto' muito mais cedo do que outros. Ou seja, não haveria uma 'dimensão de juventude' na comunidade indígena, mas sim uma clara divisão entre crianças e adultos. Por outro lado, os jovens indígenas se configuram há décadas como 'problema' devido à alta taxa de evasão escolar. O Instituto Nacional Indigenista (INI) estabeleceu já em 1968 a organiza- 
ção de faculdades com dormitórios para jovens, a maioria deles de remotos vilarejos rurais. Em termos gerais, apenas $20 \%$ dos alunos destas instituições são meninas. A demanda por este tipo de instituição vem caindo desde a introdução do Progresa - um amplo plano federal de previdência que foi desenvolvido junto a acusações de clientelismo.

Começando na presidência de Zedillo, mudanças importantes têm afetado o ensino médio, introduzindo o ensino a distância e a figura dos promotores de salud y cultura saídos de cursos patrocinados pelo INI - estes, porém, já não conseguem mais arranjar empregos relacionados à questão indígena. Acima de tudo, está faltando a ponte entre o ensino médio e o ensino superior. Para o jovem indígena, mesmo para os que são treinados pelo INI, o acesso à universidade é um sonho distante. Estas seriam razões importantes para tantos zapatistas serem jovens. Na verdade, tanto o desenvolvimento do INI — que em $1994 \mathrm{mu}$ dou a sua política oficial de indigenismo para indianismo, sugerindo que a ênfase agora não seria mais na integração, mas sim no respeito às diferenças culturais - , quanto o aumento repentino das exigências por direitos à diversidade cultural/étnica pressupõem um novo e eficiente aparelho do Estado. Ao contrário, o Estado está se afastando, cortando gastos públicos, e está abdicando o seu papel central em favor do governo local e mesmo de empresas privadas.

Durante os últimos anos, o México, e principalmente Chiapas, tem sido caracterizado por uma taxa alta de desenvolvimento econômico e por taxas baixas de desenvolvimento humano. O gasto público, que aumentou dramaticamente na década de 1970, vem caindo muito desde a década de 1980. Em Chiapas, o número de lares sustentados por mulheres tem aumentado. Isto levou a uma mudança nas estratégias de sobrevivência, com um aumento do autoconsumo e uma feminização maior da mão-de-obra agrícola. Nos municípios indígenas (aqueles onde mais de $70 \%$ da população classifica-se como indígena), a pobreza e a desnutrição ainda são muito graves. Cerca de $15 \%$ de todas as crianças morrem antes de chegar aos seis anos de idade. A taxa de analfabetismo entre as mulheres indígenas ainda é de $51 \%$.

Para completar, pode-se falar de uma rebelião de jovens tentando se afastar do controle paterno e vendo o dote como um entrave. As expectativas em relação ao parceiro ideal também mudaram. Antigamente, esperava-se que ele fosse o provedor do lar, agora a jovem espera que ele 'possa dar coisas a ela' - o poder do consumo se tornou importante. É por isso que os rapazes gostam de ter empregos como o de motorista, em vez de trabalhar na terra. Eles já não se identificam com os valores e hábitos tradicionais.

Uma das importantes mudanças recentes é que as mulheres se fazem ouvir e, afinal, o feminismo teve um efeito modernizador aqui. As mulheres es- 
tão mais interessadas na identidade étnica do que na manutenção da comunidade étnica. Atualmente, a textura da comunidade indígena já não é mais tão densa; escolhas são feitas de maneira menos coletiva do que antes. A rebelião de 1994 sancionou uma grande mudança na vida da comunidade. O zapatismo foi realmente um divisor de águas em relação aos direitos da mulher e deve ser visto como a mais recente onda de modernidade que os indígenas tiveram de enfrentar.

Sugeriria que as tendências recentes passaram a revelar um conflito entre duas noções de nação - mestiçagem versus multiculturalismo - mas isto também é o resultado de muitas outras tensões modernas. Isto reflete um grande conflito de gerações na população indígena em relação ao tipo de liderança, estrutura familiar, posição da mulher, leis consuetudinárias e novas formas de etnicidades: os jovens anseiam mais pela etnicidade, e menos pela comunidade, pelos costumes e pelas relações estreitas de parentesco. Até o momento, a categoria de 'jovem' tem estado presente entre os indígenas como uma função da "modernidade" e do desconforto com a estreita vida comunitária baseada em leis consuetudinárias. Na verdade, a demanda por um reconhecimento oficial maior dessas é algo que não parece gerar muito interesse entre os jovens indígenas típicos, mas o reconhecimento da sua diversidade dentro do 'desenvolvimento' e da 'modernidade' gera.

A maioria dos indígenas com os quais conversei sente-se irritada com as construções convencionais populares e intelectuais de uma identidade 'maia': boa quando antiga, ruim quando moderna. Uma grande e prestigiosa contribuição acadêmica nesta direção foi o chamado Projeto Harvard, que estudou os indígenas de Chiapas em etapas diferentes durante várias décadas. É claro que em Chiapas, como muitas vezes é o caso, o 'problema' local e étnico é construído no âmbito de configurações internacionais, através de agentes locais, nacionais e mesmo estrangeiros. Isto leva ao fato de que, geralmente, as reivindicações e identidades étnicas 'locais' têm apelo e seguidores internacionais, mas pouco apoio político local fora dos limites imediatos da comunidade. Obviamente, não estou propondo um isolamento metodológico impossível, nem reverenciando as identidades locais, apenas colocando que, junto à solidariedade internacional e mesmo a medidas legais, as redes (e possivelmente as alianças) políticas também precisam receber a devida atenção.

Chiapas evoluiu de uma sociedade relativamente isolada (com indígenas 'tradicionais' e o parque social jurássico dos coletos) para uma sociedade que veio à tona através da exposição mundial da mídia. Em San Cristobal, esperava encontrar uma cidade colonial tranqüila e me deparei com uma alta densidade de cybercafes e uma discoteca com sósias do Led Zeppelin tocando. 
Não existe qualquer fórum universal de organizações indígenas e ONGs; muitos reclamam da falta de funcionários qualificados locais e de esquemas de capacitação acessíveis (a universidade não é muito acessível à liderança indígena que ainda se encontra, na maior parte, presa ao nível do ensino médio). As tensões religiosas são freqüentes dentro dos grupos étnicos; e dizem que há cerca de 14 grupos armados nas florestas e nos vales desta região montanhosa - algumas pessoas até sugerem a possibilidade de futuras fragmentações da oposição (armada). Os conflitos são freqüentes entre as lideranças tradicionais, comprometidas com o establishment associado ao partido que esteve no poder ininterruptamente durante 60 anos, o PRI,14 e as formas de liderança novas e menos centralizadas. O EZLN foi um sintoma e também a fagulha de mudanças futuras. A rede de benefícios que chegou depois da revolta, e devido a ela, é um tema a ser debatido, como se deve debater até que ponto ela mudou a divisão tradicional entre os que falam e os que ficam em silêncio. A revolta certamente contribuiu para acelerar a incorporação do estado de Chiapas ao México e à 'modernidade'.

Os conflitos em Chiapas pós-1994 parecem ter uma base étnica, religiosa, de gerações e de gênero. As intervenções centradas na comunidade indígena não trataram da maioria das novas formas de auto-expressão da identidade chiapaneca. Além do mais, como uma informante no Foro sugeriu, "no hay derechos buenos y derechos malos. Hay derechos". E, acrescentou ela, construções excessivamente centradas na comunidade podem acabar criando problemas para as minorias internas ou para vozes com menos força, como a das mulheres jovens, dentro daquela comunidade.

Não tenho a impressão de que a maioria das instituições que tive a oportunidade de conhecer, apesar de brevemente, esteja completamente consciente das mudanças pelas quais os jovens estão passando - quando estavam, eu percebia um sentimento de nostalgia em relação a 'como eram as coisas' quando os jovens ainda mostravam-se, na sua opinião, interessados na luta. Depois de 1994, o número de ONGs e de instituições intervindo em Chiapas tem aumentado dramaticamente. Elas vêm contribuindo com um aumento na expressão da voz étnica e têm conferido à identidade étnica um prestígio do qual ela não gozava antes - muitas vezes fazem isto externamente.

\footnotetext{
14 Pergunto-me o que está para acontecer com esta antiga conexão da liderança indígena associada ao PRI depois que Vicente Fox, do partido PAN, venceu as eleições presidenciais.
} 
Parece que as ONGs, tanto aqui como em outros lugares, muitas vezes tendem a ficar defasadas em relação aos desenvolvimentos sociais. Em várias ocasiões, transformam-se em políticas e demandas de intervenções populares que, naquele momento, já perderam o impulso. Apesar do fato de ONGs e fundações não-governamentais muitas vezes falarem em nome da sociedade civil da qual alegam ser a voz mais democrática, elas costumam usar uma linguagem e estabelecer prioridades que estão em maior sintonia com a sociedade política e com as políticas dos seus patrocinadores (internacionais) do que com as demandas locais e específicas.

Em relação à saúde reprodutiva, acredito que haja duas dimensões seriamente pouco desenvolvidas: uma abordagem anti-racista e multicultural mais ativa, por parte dos serviços públicos, e as necessidades específicas do jovem indígena dentro ou fora das organizações indígenas.

\section{Nicarágua}

A Nicarágua foi um dos primeiros países latino-americanos, senão o primeiro, a criar um sistema de autonomia local que oferece espaços para a pluralidade dentro de parte do aparelho estadual. Ou seja, as emendas de 1987 à lei possibilitaram que a autonomia e o pluralismo étnico se tornassem pontos de partida de políticas públicas, em vez de objetivos a serem atingidos através da luta. Isto mostra a relevância da etnicidade e de mudanças em relação à etnicidade, mesmo em países periféricos (Hegg, 1997; CIDCA, 1987). De fato, ao ser comparada ao México (com as suas dificuldades em reconhecer graus limitados de autonomia para Chiapas e outros estados da Federação), ao Brasil (cuja Constituição de 1988 é muito mais avançada em outros campos), e à Colômbia (cuja Constituição de 1991 não parece ter evitado a escalada da violência), a Nicarágua pode ser considerada um exemplo positivo e corajoso.

É claro que uma lei multiétnica não torna uma sociedade etnicamente tolerante da noite para o dia, principalmente quando o país passa por uma série de tumultos menos ou mais violentos depois da transição da cleptocracia do regime de Somoza para um projeto de modernização dos sandinistas gerido pelo Estado, até chegar a uma 'economia mundializada', segundo as regras do neoliberalismo e à diminuição relativa de gastos públicos em várias áreas socialmente sensíveis durante os dois últimos governos (Chamorro e Aleman). A minha visita e os meus esforços em ler o máximo possível sobre a história e a atualidade da etnicidade e dos jovens na Nicarágua deixaram claro para mim que o país, apesar dos avanços - que são ainda mais surpreendentes quando 
se considera a conotação étnica de boa parte da violência na Costa Atlântica durante o período sandinista - , ainda tem um longo caminho a percorrer na estrada da tolerância étnica.

Em termos gerais, a Nicarágua é composta por duas grandes regiões: a Costa Pacífica e o seu interior, e a Costa Atlântica e o seu interior. Concentrei a minha visita nesta segunda região, que é vista comumente como a que representa a multiplicidade cultural da Nicarágua. Está fora do escopo deste artigo descrever de forma aprofundada a história específica e atual da Costa Atlântica. 15 Em resumo, pode-se descrever a Costa Atlântica como a região com uma história moderna de uma sociedade etnicamente plural, como a conhecemos em outras partes da bacia caribenha, principalmente mas não exclusivamente nas áreas que vivenciaram o colonialismo britânico ou holandês.

Na Costa Atlântica do que agora é a Nicarágua, cada grupo definido como étnico tinha uma posição especial no mercado de trabalho e na sociedade, segundo uma hierarquia que ia desde o branco europeu até o creole, mestizo, miskito, garifuna e sumo-mayagna. Este sistema foi incorporado ao estado da Nicarágua em 1894, mas sobreviveu com mudanças relativamente pequenas entre as décadas de 1950 e 1970 . A partir de então, duas tradiçôes étnicas entraram em confronto: a pluralista, que tinha conferido um papel especial aos creoles falantes de inglês e estava centrada nas igrejas protestantes tradicionais; e a versão nicaragüense do padrão ibérico de relações sociais, com alegações de universalismo, predominantemente católico, e conferindo um papel central ao mestizo. É apenas durante a última década que se define uma nova identidade costeña, em muitas maneiras uma mistura de elementos de identidade e culturas dos dois padrões mencionados acima. Aqui basta um retrato geral da sua composição demográfica e uma breve descrição da sua economia atual.

Em 1987, o Estatuto de Autonomia dividiu a Costa Atlântica em duas regiōes: a Norte e a Sul — respectivamente RAAN e RAAS - que correspondem a $49 \%$ do território nacional e a $9,4 \%$ da população. Também concentram a maioria esmagadora da população indígena na Nicarágua - um total estimado de $4 \%$ da população. É a região do país com maior crescimento demográfi$\mathrm{co}$, basicamente devido à imigração do mestizo e ao avanço em direção ao leste

15 Importantes fontes de inspiração são encontradas no trabalho de vários autores, principalmente Charles Hale, Carlos Vilas, Edmund Gordon, Manuel Ortega Hegg e Myrna Cunningham. 
da fronteira agrícola. Em 1980, o governo provincial fez uma projeção da população de 193.929 habitantes, enquanto Gordon (1999) calculou que seria de 282 mil. Em 1999, A Universidade da Costa Atlântica (URACCAN), citando o INEC, menciona uma cifra de cerca de 399 mil.

\section{Tabela 1}

A Costa Atlântica x o resto do país

\begin{tabular}{lrrrr}
\hline Indicadores & \multicolumn{2}{c}{ Costa Caribenha } & Nicarágua & Total \\
& RAAN & RAAS & & \\
\hline Extensão geográfica em km² & 32.159 & 27.407 & 121.428 & 59.566 \\
Porcentagem do território nacional & 26,48 & 22,57 & 100 & 49,05 \\
População total & 175.405 & 223.500 & 4.139 .490 & 398.905 \\
Porcentagem da população total & 4,24 & 5,4 & 100 & 9,64 \\
Densidade da população/ha.km & 5,5 & 8,2 & 34,1 & 7 \\
\hline
\end{tabular}

Fonte: INEC.

\section{Tabela 2}

Composição étnica da Costa Atlântica da Nicarágua

\begin{tabular}{lccc}
\hline Grupo étnico & RAAN & RAAS & Total \\
\hline Mestizos & 39,13 & 52 & 44,4 \\
Miskitos & 54,7 & 9 & 33,45 \\
Creoles & 2,48 & 34 & 17,55 \\
Garífunas & - & 3 & 1,5 \\
Ramas & - & 1 & 0,5 \\
Mayagnas & 3,69 & 1 & 2,6 \\
Total & 100 & 100 & 100 \\
\hline
\end{tabular}

Fonte: INEC. 
Durante décadas, a região Atlântica tem sido considerada a fronteira rural e de mineração da Nicarágua. A migração da região da Costa Pacífica foi estimulada durante o governo de Somoza e tem continuado desde então. Os imigrantes são mestizos, geralmente camponeses e pequenos empresários. A sua chegada tem causado atritos. No Sul, eles ameaçam os interesses dos creoles falantes de inglês, que costumavam chamar os imigrantes de forma pejorativa simplesmente de Spanya, e no Norte, o seu assentamento em áreas rurais tem provocado ressentimento por parte da maioria da comunidade miskito em relação a questões de posse de terra - este é o único grupo que produziu um partido relativamente forte, com representantes com base étnica no governo local (o Partido Misurasata).

Há vários dados importantes para se compreender a situação presente: o país importa três vezes mais do que exporta; o seu produto interno bruto (PIB) é um dos menores da América Central; boa parte da população vive nos Estados Unidos (o que torna a dependência deste país ainda maior do que sempre tem sido na história moderna); a taxa de natalidade é a mais alta da América Latina (e a taxa de gravidez de adolescentes também é: 152 entre mil adolescentes engravidam);16 e atualmente o país gasta muito menos com problemas sociais do que outros países latino-americanos. Além disso, a sua polícia deixou de ser a máquina eficiente (embora repressiva, segundo algumas pessoas) do período sandinista, tornando-se uma instituição muito mal remunerada e profundamente afetada pela corrupção e pelo apelo do narcotráfico.

Entrevistei várias instituições na capital Manágua, e depois peguei um avião para Bluefields, capital da RAAS, e Puerto Cabezas/Bilwi, capital da RAAN. As entrevistas em Bluefields e Puerto Cabezas me ajudaram a ter uma primeira idéia sobre a questão polêmica levantada por esta pesquisa na Costa Atlântica. Também pude aproveitar dois resultados recentes de pesquisas sobre a condição dos jovens em, respectivamente, Puerto Cabezas 17 e Bluefields (Machado, 1998).18

\footnotetext{
16 Fonte: Boletín de la Red de Investigadores en Análisis Sociocultural y Demográfico, n. 2, 2000.

17 Sou grato a Carlos Aleman, da Clinica Bilwi, pelas informações sobre as descobertas feitas na pesquisa em Puerto Cabezas.

18 Um importante obstáculo foi a falta geral de indicadores numéricos oficias ou confiáveis. Os dois trabalhos que mencionei parecem ser os únicos que enfocam os temas fundamentais deste artigo. O primeiro foi realizado em Puerto Cabezas, de 1994 a 1996, como parte das atividades da ONG Wanghia Lupia; o segundo foi um projeto mais amplo que entrevistou 460 jovens em Bluefields, em 1998, e foi patrocinado pelo Catalan Fund for Cooperation.
} 
A situação do emprego é caracterizada por desemprego crônico, migração externa e - na opinião de vários porta-vozes creoles - uma crescente passividade entre os jovens, principalmente entre os de origem creole. Segundo os resultados das duas pesquisas, o desemprego entre os jovens em Bluefields e Puerto Cabezas varia de 80 a 90\%. Em relação a Bluefields, o Sr. Tubbs, comerciante de médio porte em matérias de construção do Bloco Costeño, me disse que, hoje em dia, é difícil encontrar um carpinteiro creole jovem, porque eles preferem ir embora em um navio estrangeiro. O reverendo Faran Demetz, reitor da Bluefield International Christian University (BICU), da Costa Atlântica, declarou que está cada vez mais difícil recrutar bons alunos creoles para a sua universidade, que é administrada sob o patrocínio da Igreja Moraviana e na qual parte das aulas é dada em inglês - a maioria das novas matrículas é de mestizos, que são principalmente católicos, mas que estão ansiosos para aprender inglês. Demetz afirma que os rapazes creoles preferem se tornar marinheiros a estudar para ter um diploma.

Pegar um navio significa ganhar dinheiro mais rapidamente do que em outras ocupações ou profissões - mesmo que isto ofereça pouca mobilidade social a longo prazo - além de permitir que sintam o gosto do mundo estrangeiro e de ser uma oportunidade concreta de se migrar para os Estados Unidos. Isto costumava ser uma prerrogativa dos creoles, pois eles tinham a vantagem de dominar a língua inglesa. Agora também é o caso de um número cada vez maior de rapazes mestizos. Isto diz respeito apenas a navios de cruzeiros, enquanto os pesqueiros ainda são artesanais e bastante locais ou barcos estrangeiros com tripulações estrangeiras - a maioria de Honduras. Em Puerto Cabezas, os rapazes têm uma boa alternativa de ficar 'sem fazer nada': tornamse mergulhadores (buzos) para os vários barcos de pesca de lagosta que varrem as águas de Cayos Miskitos. Ouvem-se vários boatos sobre o estilo de vida dos buzos - pelo que sei, nenhuma pesquisa mais aprofundada foi realizada sobre os marinheiros de Bluefields nem sobre os buzos de Puerto Cabezas. Os trabalhos de marinheiro ou buzo são atividades masculinas, baseadas na distância geográfica dos parentes e da própria família.

O número geralmente mencionado de 10 mil marinheiros e a vagarosa, porém constante, migração externa para os Estados Unidos (os mestizos de classe baixa tendem a migrar para a Costa Rica porque, segundo me disseram, não têm a vantagem de falar inglês nem os contatos nos Estados Unidos que os creoles já desenvolveram) não apenas são relevantes para a situação do emprego, mas também revelam as antigas e novas conexões transnacionais que significam um certo grau de exposição à globalização. Há, no entanto, um lado mais sombrio neste recente impulso em direção à globalização. 
O uso da cocaína é um problema sério em toda a Nicarágua e, de acordo com algumas pessoas, especialmente na Costa Atlântica.19 Uma pesquisa recente sobre o uso de drogas em Bluefields, coordenada pelo político local de esquerda, Moises Arana, que ainda não tinha sido publicada quando eu estava lá, contou até 260 pontos de venda de cocaína (espendios). A pesquisa feita por Carlos Aleman e sua equipe, em Puerto Cabezas, registrou 86 pontos de venda - quase todos concentrados em dois bairros, onde a venda de cocaína se tornou uma atividade econômica importante. $\mathrm{Na}$ costa, a cocaína veio do mar de forma quase milagrosa. Tudo começou depois da derrota sandinista. Cartéis colombianos, percebendo um relaxamento da polícia e do controle do exército, começaram a usar as pequenas ilhas na costa como parte da sua rede. Os jornais falavam sobre cocaína que tinha caído ou sido jogada de barcos e que chegava à costa. Era vista como um presente de Deus, como tudo o que vem do mar. Mito ou realidade, isto não impede que o preço da cocaína seja muito baixo - menor que o da cerveja ou da maconha, ambas produzidas localmente.

Ouve-se falar, também, que o uso da cocaína está aumentando muito nos vilarejos rurais e pesqueiros, que comunidades miskitos inteiras foram desintegradas pelo seu influxo repentino, e que pescadores trocam lagosta por cocaína em mar aberto. Pessoalmente, no entanto, pude ter uma idéia sobre a seriedade do problema devido ao grande número de pedreros (usuários de cristal de crack) concentrados e negociando a droga nas ruas do centro de Bluefields e Puerto Cabezas durante a noite. Para piorar a situação na costa, não há qualquer instituição eficiente que lide com este problema crescente. Por outro lado, soluções tradicionais para problemas sociais locais estão provando ser ineficazes. Por exemplo, o serviço social e o aconselhamento tradicional ligado à Igreja (Moraviana) têm demonstrado falta de coragem. Segundo o reverendo Demetz a Igreja Moraviana, que ainda não se recuperou do trauma da guerra - quando era vista como uma entidade anti-sandinista _ , tem mostrado uma capacidade ainda menor para lidar com os desafios da situação atual. Os reverendos, que no passado eram a vanguarda do serviço social, se voltaram, na maioria, para rixas teológicas, fazendo com que a Igreja Moraviana perdesse boa parte do apelo para os jovens - que agora só freqüentam a igreja quando

\footnotetext{
19 Outros defendem que, ao contrário, artigos recentes em jornais nacionais associando a Costa Atlântica ao crescimento no tráfico e no uso de drogas são, na maioria, parte da criação de um estereótipo desta parte 'diferente' da Nicarágua.
} 
obrigados. Nos sermões, os (jovens) usuários de drogas são vistos como almas perdidas. Por outro lado, soluções modernas continuam sendo aguardadas.

De muitas maneiras, a venda de cocaína é tão devastadora quanto o seu uso regular no que diz respeito à vida familiar, a papéis de gênero e manifestações públicas de masculinidade e feminilidade. Em Puerto Cabezas, muitos rapazes vêem a venda da cocaína como uma forma de ajudar a família a sair da pobreza. No entanto, todos acabam vendendo para os seus vizinhos e amigos e, através disso, desintegrando a vida em família. É claro, há também conseqüências importantes quanto à escolha de um parceiro e ao grupo de possíveis parceiros. Mesmo que os ganhos com a venda da cocaína sejam menores do que o esperado, eles geralmente são maiores do que os de pequenas atividades informais, que são as únicas alternativas disponíveis para os rapazes locais com pouco estudo. Diante disso, o rapaz com mais dinheiro se torna um melhor parceiro. Ao que parece, depois da primeira grande campanha informativa em 1997-1998, as pessoas passaram a conhecer melhor os perigos da cocaína. Ainda assim, a maioria dos jovens, sem distinção, ainda a consome.

A gravidez na adolescência é denunciada como um problema sério, embora eu não tenha conseguido encontrar indicadores numéricos locais confiáveis. Aparentemente, isto nunca foi raro na cidade e agora está se tornando comum nos vilarejos menores, também entre os miskitos, principalmente entre os que se mudaram para a cidade. A maioria dos informantes também está preocupada com o aumento da prostituição, embora, mais uma vez, não tenha encontrado indicadores numéricos confiáveis. Do final da tarde até o amanhecer, (jovens) prostitutas (sem predominância de um grupo étnico, mas geralmente de pele escura, mesmo quando mestizas) podem ser vistas em lugares-chave nas duas cidades que visitei. Quando os buzos voltam do mar, dezenas de moças estão esperando por eles - geralmente adolescentes - no píer de Puerto Cabezas. Nas duas cidades, como em muitas pequenas cidades que conheço no Brasil ou no Suriname, geralmente é difícil diferenciar entre uma prostituta profissional e uma 'menina esperta' e com experiência de rua. A maioria das meninas nunca se veria desta maneira - mas sim como mulheres que lutam para sobreviver.

A alta incidência de uso de cocaína, a falta de acesso a serviços de saúde e prevenção, e a pobreza abrangente criaram um contexto problemático para a saúde reprodutiva, embora, segundo a Comisión de Lucha contra el Sida de Puerto Cabezas, isto ainda não tenha resultado em números elevados (oficiais) de infecções por HIV. De acordo com os números oficiais, há 400 casos registrados de Aids na Nicarágua. Na região de Puerto Cabezas, onde os pesquisadores trabalham, sabe-se que há oito casos de presença do vírus HIV, mas 
nenhum de Aids. Eles trabalham com prevenção e têm se concentrado em dois grandes grupos de risco: os buzos e as prostitutas. O primeiro grupo volta à costa a cada 15 dias e passa boa parte dos dias de folga. Gasta a maior parte do dinheiro no que chama de 'viver': um longo fim de semana com bebida, cocaína e prostitutas.

As prostitutas, na maioria miskitas, assumem muitos dos traços culturais dos creoles, inclusive do inglês creole, que está se tornando o idioma-ponte do submundo (e, em menor parte, da cultura jovem). Elas formam um grupo de 30 a 35 prostitutas, que é pequeno em termos percentuais. Muitas vezes se recusam a usar preservativo, pois sem ele podem ganhar 100 pesos, enquanto ganhariam apenas 40 se o usassem. Apesar desta resistência, houve uma melhoria na distribuição gratuita de preservativos.

Não há uma cena gay aparente em Puerto Cabezas (também não vi alguma em Bluefields ou Manágua). Christian e Domingo conseguiram, depois de muitos esforços, se reunir com um grupo de homossexuais, que saíram dos seus esconderijos e até organizaram festas públicas. Este grupo ativo está consciente da importância do uso de preservativo. As mães adolescentes estão se configurando como um novo grupo social. Elas sempre existiram entre os miskitos, mas atualmente tendem a ser tornar mães solteiras e a ser sustentadas pela família materna. 20 Ao todo, há 500 ou 600 casos de doenças sexualmente transmissíveis registrados na região da cidade. Segundo os informantes, as comunidades rurais ainda condenam bastante o uso da cocaína - apesar de certamente estarem sofrendo com isto. Por isso, os jovens tendem a vir à cidade para consumir a droga - longe dos olhos de seus parentes.

Estes problemas precisam ser colocados no contexto desta região multiétnica com conexões transnacionais, resultado não apenas das redes de contato da Igreja Moroviana, mas também da guerra que terminou somente uma década atrás, da migração, da tradição dos marinheiros e, mais recentemente, da atuação internacional das redes de cocaína. A região também tem conhecidas conexões étnicas transnacionais há muito tempo. Os miskitos e os garifunas são povos bi ou trinacionais (presentes em Belize, Honduras e Nicarágua); os afro-caribenhos falantes de inglês e, mais recentemente, o mundo afro-ameri-

\footnotetext{
20 Sugiro que se observe com cuidado esta tendência de se passar de mãe adolescente dentro de um casamento tradicional, possivelmente em uma comunidade (quase) rural, à mãe solteira, apesar de haver a visita de um homem, possivelmente em uma vizinhança do que se tornou uma cidade. Esta tendência é tanto causa como efeito de mudanças importantes no desempenho da masculinidade entre os jovens miskitos.
} 
cano são muitas vezes os horizontes culturais e políticos dentro dos quais um grande número de creoles têm tradicionalmente se situado - como dizem, muitos se sentiram primeiro morovianos e/ou afro-caribenhos e, depois, nicaragüenses. Na Nicarágua, as relações raciais podem ser mais bem descritas como uma série de encontros entre as construções de mestiçagem, cada uma delas com discursos e estilos específicos, que se confrontam umas com as outras: mestizos, creoles, miskitos. Há uma linha tênue entre negro, branco e indígena nativo. Diferenciar o 'negro' ou o 'branco' do resto pode ser difícil.21

Os miskitos estão se tornando mais importantes em termos numéricos e também políticos. Em parte, isto está relacionado ao fato de que eles incorporam indivíduos vindos de fora, como os creoles e mestizos natos. No entanto, é possível que tenham uma taxa de natalidade comparativamente mais alta não há indicadores numéricos disponíveis sobre a taxa de natalidade por grupo étnico. A migração externa de creoles abriu algumas posições na máquina estadual e educacional que uma parte dos miskitos agora está ocupando.

Muitos creoles se sentem invadidos por gente de fora. Crêem que estão perdendo os pequenos privilégios que lhes foram concedidos por dominarem o idioma inglês e um certo nível de habilidades técnicas durante a época em que a região dependia basicamente do colonialismo britânico e, posteriormente, das empresas americanas. Também acham que estão perdendo o controle político e cultural da sua cidade, das escolas religiosas e da política local - pela primeira vez, o prefeito de Bluefields é um mestizo e não há qualquer candidato creole importante para a próxima eleição. No entanto, embora a presença demográfica creole esteja diminuindo, a sua influência cultural continua forte - mais um exemplo de que a força de uma cultura não depende apenas da demografia. Eles também têm uma boa representação nas ONGs e fundações locais. 22

O multiculturalismo oficial é basicamente pobre e tem falta de funcionários qualificados. No ensino fundamental, a educação multicultural signifi-

\footnotetext{
21 Quanto a isto, não posso concordar com várias declarações radicais que tendem a simplificar excessivamente o sistema de relações étnicas e raciais na região. Infelizmente, exemplos destas declarações são encontrados no panfleto Minority Rights Report on Afro-Central Americans, publicado em 1996: "Na Nicarágua, comunidades negras vêm perdendo terreno para os mestizos há mais de um século, levando a revoltas repetidas".

22 Francisco Campbell, da FACANIC (uma das principais federações de ONGs da Costa Atlântica nicaragüense), enfatizou a importância econômica destas instituições que, segundo as suas estimativas, empregam na RAAS e na RAAN de 400 a 450 pessoas e administram um orçamento de cerca de 2,5 milhões de dólares por ano. Estes empregos são uma arma importante na luta contra a evasão de cérebros.
} 
ca, na maioria dos casos, que professores que não falam inglês dão as aulas no seu idioma materno, geralmente em miskito - para o desalento dos pais que desejam que os seus filhos aprendam espanhol e inglês, embora tenham uma atitude positiva em relação ao fato de parte do ensino ser em 'língua étnica'. No ensino superior, a efetivação de algum tipo de multiculturalismo parece ser mais fácil. Mas tudo isto ainda está muito longe das necessidades da sociedade costeña e da vivacidade do uso criativo dos símbolos étnicos da cultura jovem da região - que se alimenta da música popular que se vende como 'costeña' e 'tropical'. Além do mais, estas vivências de uma nova identidade costeña multiétnica e híbrida ainda não são totalmente reconhecidas pelos partidos políticos locais e nacionais.

Para concluir, de uma maneira que faz lembrar Chiapas, a Costa Atlântica da Nicarágua passou, em um período de tempo relativamente curto, de um isolamento a uma incorporação abrangente e problemática ao resto do país. Os fluxos culturais e econômicos associados à 'modernidade', que no passado se relacionavam apenas a uma parte da população, agora têm um impacto maior do que antes.

\section{Colômbia}

Dos três países estrangeiros que visitei, a Colômbia certamente é o que apresenta mais semelhanças com o Brasil, em termos de relações raciais e de cultura negra. A Colômbia possui a segunda maior população de origem africana na América Latina depois do Brasil. Este grupo, que se calcula ser de mais de $18 \%$ da população local, se concentra na Costa Pacífica, na Costa Atlântica e no Vale do Rio Cauca (sendo Cáli a sua cidade principal), mas também é visível em outros lugares. Devido às migrações internas e ao êxodo em consequiência da guerra de guerrilha e antiguerrilha (desplazamiento) mais recentemente, uma grande população negra agora também pode ser vista em Medelin e mesmo em Bogotá.

A Colômbia, exatamente como o México, a Nicarágua e o Brasil, fez da sua mestiçagem biológica e cultural o cerne da sua auto-representação nacional. Tradicionalmente, no entanto, há uma diferença em relação ao Brasil: os retratos e discursos populares e de elite sobre a mistura racial tendem a ser sobre o par branco-indígena. Pessoas de descendência africana geralmente têm estado menos presentes nestes discursos, apesar de representarem um grupo muito maior do que o indígena.

Durante as duas últimas décadas, esta conjuntura começou a mudar. Isto resultou em uma nova constituição em 1991 (Lei 70), que declarava que a 
Colômbia deveria ser um país multiétnico e multicultural, e estabelecia direitos de posse de terra especiais aos descendentes das comunidades maroons (em português, quilombolas), como também uma representação - de breve duração - no parlamento destas comunidades e das comunidades indígenas. Por um lado, estas mudanças legais significaram um grande passo à frente em termos de reconhecimento da diferença étnica; por outro lado, representaram problemas novos porque: 1 ) de uma forma que não pôde ser prevista, abriram o caminho para um processo de etnogênese em um país cuja textura social foi e é marcada pela guerrilha e pela violência (para)militar; 2) diziam respeito apenas a comunidades coesas, rurais e etnicamente marcadas, deixando de fora a maioria da população de descendência africana (mista) que cada vez mais tende a ser urbana e a ser definida racialmente em vez de etnicamente (para as pessoas de fora, eles "têm uma aparência diferente" mesmo que raramente "se comportem de forma diferente"); e 3) criaram expectativas que não podiam ser satisfeitas especificamente em um contexto de afastamento rápido do Estado de áreas fundamentais para as políticas multiculturais, como a educação e a criação de empregos.

Um outro aspecto que faz com que a Colômbia seja relativamente semelhante ao Brasil é que existe agora uma tradição de pesquisa consolidada sobre o tema das relações raciais e da cultura negra (tanto em áreas rurais quanto urbanas), 23 como também sobre a saúde reprodutiva e a população de descendência africana (ver, entre outros, Viveros Vigoya, 2000). Se o Brasil está mais adiantado no primeiro tópico - e os pesquisadores colombianos contam bastante com a literatura brasileira — - a Colômbia está mais adiantada no segundo.

Concentrei-me em duas cidades e suas regiões, Cáli e Cartagena, onde fiz o melhor possível para ter uma idéia visual das condições de vida de várias vizinhanças, cidades e vilarejos com uma grande maioria de afro-colombianos. Na região de Cáli, visitei a cidade agrícola de Puerto Tejada e a cidade portuária de Buenaventura, com mais de 250 mil habitantes, a maior cidade da Costa Pacífica colombiana. Perto de Cartagena, visitei o vilarejo de Palenque, simbolicamente muito importante para os ativistas afro-colombianos, que o identificam como o lugar onde os traços da cultura africana foram mais

\footnotetext{
23 Uma lista de pesquisadores importantes deve incluir Nina de Friedmann, Jaime Arocha, Fernando Urrea, Gustavo Ignacio de Roux, Eduardo Restrepo, Adriana Maya, Mara Viveros e Claudia Mosquera. Vários estudiosos estrangeiros consagrados também têm estado ativos neste campo na Colômbia, como Peter Wade, Michel Agier, Christian Gross, Olivier Barbari, Odille Hoffman e Michel Taussig.
} 
bem mantidos na Colômbia. Também visitei Bogotá, onde me limitei a contatos acadêmicos.

Cáli foi escolhida por ter a minoria negra, apesar das alegações oficiais de que os afro-colombianos estão concentrados, principalmente, apenas ao longo da Costa Pacífica (que está a menos de três horas de carro da cidade). Com uma área metropolitana apresentando uma população de 2,75 milhões de habitantes, entre os quais $34 \%$ são negros ou mulatos, Cáli é, sem dúvida, a maior concentração de afro-colombianos. É, de muitas maneiras, central para a região do Pacífico, da qual, disseram, está rapidamente se tornando a capital cultural. O principal festival de música e cultura do Pacífico é realizado em Cáli em agosto.

Também escolhi esta cidade porque ela é a base do programa de pesquisa mais elaborado e adiantado sobre relações raciais, juventude negra e, durante os últimos anos, saúde reprodutiva e/na condição racial (ver Quintin Quilez, 2000; Urrea, 2000a, 2000b). Ali, concentrei minhas visitas no distrito de Aguablanca, um grande conglomerado de classe baixa de favelas, fronteira com um número cada vez maior de assentamentos precários de posseiros, que cresce cada vez mais com a imigração constante de pessoas deslocadas pela violência, sobretudo da Costa Pacífica esmagadoramente negra. Perto de uma infra-estrutura que estava tendo um certo sucesso no combate daquela que podemos chamar de 'pobreza tradicional', sente-se a carência de medidas e estruturas para o combate destas novas formas de pobreza associadas à migração, que estão submetendo o tecido social (ajuda mútua, associações de moradores etc.) dos bairros populares mais tradicionais a uma forte pressão. Isto, acima de tudo, estava ocorrendo ao mesmo tempo em que o Estado se afastava da intervenção social devido a planos econômicos nacionais para a 'recuperação' econômica.

A criminalidade juvenil (freqüentemente organizada em gangues ou pandillas), combinada à violência dos esquadrões da morte, tornou-se onipresente nesta região até mesmo durante o dia. Fiquei impressionado com o fato de que, em Cáli, Buenaventura e, um pouco menos, em Cartagena, os meus informantes nunca incluíam o uso de cocaína (popularmente chamada de perico), crack (bazuco) e cola de sapateiro como um sério problema local. Eles colocaram que, para os jovens que trabalham com isto, é a venda de cocaína e o mecanismo de vingança a ela associado que constituem o perigo.

A elite política de Cáli sempre manteve uma relação problemática com a população afro-colombiana - paternalista na melhor das hipóteses. Muitas publicações defendem que, se a maioria dos negros é pobre, é por causa da sua cultura e porque os negros não se incomodam em viver em áreas insalu- 
bres, uma vez que já devem ter se acostumado a isto. Muitas vizinhanças com grandes populações negras recebem o nome do político que foi o seu 'benfeitor'. Apesar da preferência pela esquerda entre a maioria dos líderes comunitários negros na história da cidade, foi o Partido Liberal conservador, graças ao grau de cooptação e uso de slogans populistas (também incorporando traços da cultura negra), que mais se beneficiou da luta negra em termos eleitorais. Apenas recentemente, a elite local começou a aceitar que Cáli tem uma grande minoria não-branca/mestiça. Esta mudança está relacionada à popularidade crescente de eventos como o grande Festival de Música do Pacífico, que tem sido realizado com verbas do município durante os quatro últimos anos (1997-2000).

Pesquisas sobre a estrutura familiar em Cáli indicam que, como se esperava, as famílias negras tendem a ser mais pobres; que a mobilidade social ocorre sim, porém é mais difícil; que a mestiçagem continua; e que, em termos gerais, as diferenças entre brancos e negros é mais acentuada no grupo intermediário do que nas classes mais pobres e nas seções mais ricas.

Pesquisas sobre a masculinidade (hombria) estão demonstrando que as construções familiares tradicionais estão mais frágeis do que nunca, porque cada vez menos mulheres jovens aceitam o poder de um homem sem questioná-lo, principalmente se o homem não é realmente o provedor, mas fingem que ele é diante dos amigos e parentes dele. Homens e mulheres jovens sentem-se deslocados pela falta de empregos adequados, ao mesmo tempo em que nem todos são capazes ou estão dispostos a competir no mercado de atividades econômicas informais (rebusques).

Durante estes anos, como meus informantes têm percebido no bairro de Aguablanca, em Cáli, o casal tem se tornado uma unidade cada vez mais frágil entre os jovens. Entre eles, a vida a dois simplesmente tende a ter uma duração mais curta. A maioria das jovens com as quais esta organização está em contato vivencia o que na antropologia é conhecido como monogamia serial. Durante este mesmo período de tempo, a iniciação sexual passou a ocorrer antes dos 14 anos de idade. Segundo alguns informantes, ademais, a maioria das mulheres jovens prefere parceiros de fora do seu bairro - sugerindo que os rapazes locais são maus parceiros.

Cartagena de las Indias, com uma área metropolitana com 1,28 milhões de habitantes, entre os quais aproximadamente $70 \%$ são negros e mulatos, é a segunda cidade depois de Barranquilla e tem a maior concentração de afrocolombianos na Costa Atlântica. As grandes usinas petroquímicas construídas na década de 1960 modernizaram a cidade e deslocaram parcialmente a elite local. Cartagena é a capital de uma região caracterizada por grandes proprie- 
dades rurais para a pecuária; desde os anos 1970, uma grande parte destes latifúndios vem sendo comprada pelos barões das drogas.

A cidade apresenta semelhanças e diferenças em relação a Cáli. As semelhanças são a presença conspícua de uma população deslocada das áreas rurais, onde guerrilhas e principalmente paramilitares vêm espalhando o terror; falta de serviços sociais; uma tradição de racismo por parte da elite local; e vitalidade cultural entre os jovens afro-colombianos através de formas originais de música e dança. As diferenças são a alta incidência do uso de drogas na classe baixa e a importância da indústria do turismo para a economia e representação pública de Cartagena - o impacto do turismo em Cáli é mínimo em comparação a Cartagena. Esta, com as suas praias e seu belo centro histórico (declarado monumento mundial pela Unesco), tem, durante décadas, atraído um grande número de turistas nacionais e estrangeiros.

O turismo levou à transformação de uma série de imagens e artefatos associados aos afro-colombianos em ícones turísticos, como as mulheres palenqueras 24 (que lembram a forma através da qual a indústria de turismo em Salvador, na Bahia, transformou a baiana do acarajé em um ícone) e ornamentos afro para o cabelo (que as mulheres afro-colombianas colocam no cabelo de turistas - brancos na maioria - , na praia de Boca Grande, onde se concentra a maioria deles). A partir da incorporação ao universo da música popular, passou a aconteceu um grande consumo de gêneros de músicas e instrumentos musicais, geralmente associados à população negra. Assim, foi sendo criada a noção de 'música tropical' (Wade, 2000). Cartagena lembra muito Salvador, e não apenas pela sua bela arquitetura colonial, mas também pelos traços endogâmicos da elite local, contrabalançados por uma vitalidade cultural e um orgulho étnico renovados entre o grupo jovem da população negra.

Os discursos dos oito ativistas negros que entrevistei também fazem lembrar do Brasil. Eles reforçam a idéia de que a identidade negra e a diferença precisam ser enfatizadas para serem redescobertas. Insistem em usar o termo 'negro' como uma afirmação política contra a tentativa de tornar a negritude invisível. O vilarejo de Palenque, a 60 quilômetros da cidade, é identificado por estes ativistas como a fonte principal de símbolos negros. Palenque é uma grande comunidade rural formada por descendentes de escravos fugitivos há cerca de duzentos anos. Conta com rituais funerários específicos, estilos de

24 Mulheres negras, originalmente do vilarejo de Palenque, que vendem, geralmente em grupo, frutas e legumes em grandes bandejas de metal levadas em cima da cabeça pela da cidade. 
música e um amplo léxico popular com base bantu. Em Cartagena, no entanto, a maioria dos jovens negros expressa a sua combinação de juventude e identidade étnica através do gosto coletivo por estilos musicais que são comumente vistos como costeños, 25 ou negros, como vallenato e champeta (Mosquera \& Mercado, 1989; Wade, 2000).26 Uma outra queixa relacionada é que a cidade é geograficamente segregada, com uma faixa de classe alta e média ao longo da costa e uma imensa área de classe baixa perto dos mangues e pântanos. Cada novo plano turístico tem sido acompanhado pela expulsão da maioria da população negra de uma área central para uma área distante, sem infra-estrutura.

Os ativistas entrevistados denunciam com força a falta de consciência negra. Sugerem que esta falta resulta do fato de que a escravidão era basicamente doméstica na região - apesar de a cidade ter sido o porto de entrada dos escravos para o império espanhol. Há uma continuidade do passado. Os negros procuram soluções individuais, tentam fazer amizade com a elite - que responde com paternalismo - tratando a pessoa com frases como " $\mathrm{sim} /$ não, meu filho". A elite, por um lado, nega o racismo e insiste que são apenas as nefastas influências externas que reclamam disto; por outro lado, tende a criar vários contextos informais nos quais os contatos raciais parecem muito igualitários e acabam funcionando como um tampão para tensões raciais (situaciones tu a tu).

Mais um aspecto parecido com a região metropolitana de Salvador, onde fiz pesquisa de 1992 a 1996, é uma profunda e problemática mudança na relação entre trabalho e jovens, sobretudo os de baixa escolaridade. Os informantes denunciam o desemprego, que, diz-se, nesta região é o mais alto na Colômbia e também afeta pessoas com diplomas universitários. Enquanto isso, os jovens têm uma perspectiva diferente da dos seus pais em relação ao trabalho: desejam uma colocação adequada (empleo) e já não se satisfazem mais com atividades informais (rebusque). Já que não há trabalhos adequados para a maioria dos jovens locais, e devido ao fato de que eles não se interessam muito por trabalhos manuais, boa parte das atividades artesanais tradicionais desta região está desaparecendo. Objetos que anteriormente podiam ser consertados localmente, agora são jogados fora.

\footnotetext{
25 Em muitas situações, este termo, além de expressar uma identidade nacional, também é relacionado à cor escura da pele da maioria dos habitantes da Costa Atlântica.

26 A mistura local de house, soul e, principalmente, de vários estilos musicais 'africanos' que os DJs mixam e tocam em dezenas de sistemas de som com pistas de dança anexas, que ganham vida durante os fins de semana em bairros predominantemente de classe baixa.
} 
Informações sobre como tomar decisões a respeito de sexualidade são extremamente necessárias. As ONGs tentam incorporar isto na maioria das atividades. Não há qualquer serviço público fazendo algo parecido. No centro da cidade, há o centro governamental da agência Profamilia, mas que não faz nada além do mero controle da natalidade. A recém-lançada cadeira universitária sobre Saúde Sexual poderia ter realizado algo de positivo, mas a sua ênfase é apenas nos aspectos médicos - e é muito biologista.

\section{A questão polêmica: saúde reprodutiva, etnicidade e exposição à globalização}

Ao se comparar estes quatro países, observa-se diferenças importantes em termos de tamanho, composição das populações 'negras' e 'brancas', histórico de violência, história étnica, discursos nacionais e construção da 'raça',27 história sexual e moral, grau de intervenção estadual, infra-estrutura pública, presença de fundações estrangeiras e grau de organização do ativismo negro. No entanto, em resumo, em todos os quatro países, as tendências na saúde reprodutiva e nas relações raciais e identidade étnica podem ser esboçadas segundo uma série de traços comuns. Um dos traços fundamentais é que, nos quatro países, no passado recente, importantes mudanças legais têm produzido uma legislação geralmente abrangente e progressista no que diz respeito aos temas principais deste trabalho: direitos das minorias étnicas, direitos sobre a saúde reprodutiva e direitos das crianças e dos jovens. $28 \mathrm{O}$ cumprimento destas leis e cartas de direito é, contudo, bastante problemático devido a uma falta de investimentos e infra-estrutura nestes campos de ação social. Nos quatro países, a continuidade é um problema sério. Intervenções são iniciadas e interrompidas muito mais por razões de financiamento e administração do que por mudanças no contexto social. Muitas ONGs e fundações estrangeiras se retiraram da Nicarágua e, mais recentemente, da Colômbia. Em Chiapas ocorre o oposto: fundações e ONGs 'descobriram' a região depois da rebelião armada de 1994.

\footnotetext{
27 Nas estatísticas oficiais apenas o Brasil e, de certa forma a Nicarágua moderna, incluem o item cor. Na Colômbia, o departamento nacional de estatística está começando somente agora a experimentar com o item cor ou ' raça'.

28 Estou me referindo, entre outras, a uma série de iniciativas como o Estatuto da Criança e do Adolescente no Brasil e a estatutos parecidos na Nicarágua e na Colômbia. Ainda preciso verificar a situação do México.
} 
Outras tendências inter-relacionadas são as seguintes:

1) Dentro de um quadro de queda no crescimento populacional, há um aumento no número de mães solteiras e, com isto, na gravidez na adolescência. A condição de mãe solteira não é mais, em relação ao passado, apenas um estágio na careira matrimonial da mulher. É uma condição a longo prazo.

2) Estruturas familiares foram afetadas de várias maneiras pela individualização. Por exemplo, é menos comum do que antes que pais abdiquem o seu tempo livre e a sua renda para cuidar de parentes ou de filhos grandes. Como resultado, mães solteiras não podem mais contar tanto com as suas próprias mães para cuidar dos seus filhos.

3) Existe uma profunda e contínua crise entre os provedores masculinos devido ao colapso da estrutura salarial para o trabalhador não-especializado nas regiões urbanas.

4) Observa-se o que se pode chamar de popularização do 'amor romântico' e de certas questões feministas nas camadas sociais mais baixas que vinham até então sendo consideradas relativamente independentes destes fenômenos. Um número crescente de mulheres jovens escolhe os seus parceiros, levando também em consideração a quantidade de amor e o prazer que eles podem lhes proporcionar.

5) A popularização do uso da cocaína e dos seus derivados. As conseqüências deste uso para a vida em família e para as relações de gênero têm sido, até agora, pouco enfatizadas tanto na pesquisa quanto na intervenção.

6) A criminalidade, (as gangues ou pandillas e envolvimento com os escalões mais baixos das redes de drogas), o uso de drogas e a violência policial - geralmente estes três fatores são interconectados - são as causas principais da morte de homens jovens. Isto vem reduzindo ainda mais o grupo de homens em condição de casamento - a cesta dos parceiros.

7) Este 'grupo' também é afetado pelo fato de que as mulheres jovens, principalmente nos grupos de classe baixa, tendem a ter um desempenho escolar melhor do que o dos homens jovens. Isto configura uma dramática mudança nas gerações, uma vez que mostra uma inversão da situação passada, na qual as mulheres tinham um nível educacional menor. É claro, esta melhoria no nível educacional das mulheres jovens está ocorrendo dentro de um contexto de uma piora rápida na qualidade do ensino público - que, no Brasil, possivelmente é mais acentuado do que nos outros três países. O ensino se expandiu, mas é de qualidade ruim (não está melhorando tanto, nem na medida nem na direção exigidas pelo mercado de trabalho) e apresenta altas taxas de evasão escolar. Reivindicações quanto a um ensino anti-racista e ao uso de campanhas escolares sobre os direitos de saúde reprodutiva precisam se dar conta desta realidade do ensino público. 
8) A noção de 'parceiro ideal' está mudando rapidamente — o marido e a mulher esperam coisas novas e diferentes das do passado. Um número cada vez maior de jovens, talvez principalmente de homens jovens, não consegue competir de forma 'justa' no mercado matrimonial - e se sente excluído.

9) O enfoque da identidade da juventude em torno do consumismo, em vez da própria função no processo de produção, que está se tornando cada vez mais rarefeito, tem implicações sérias na construção dos papéis e das relações de gênero. A polaridade tradicional honra/homem versus vergonha/mulher está sendo redefinida em torno de uma polaridade um pouco diferente - reputação/homem versus respeitabilidade/mulher.

10) Um grande grupo de jovens, principalmente de homens jovens, sente-se mais incerto do que nunca em relação ao seu papel de gênero - como um homem típico deve se comportar. Isto leva a uma demanda crescente por igualdade em papéis de gênero, o que causa uma confusão na construção da masculinidade centrada no poder e nos privilégios masculinos inquestionáveis.

11) A violência doméstica e a negligência dos filhos são mais explícitas do que antes. Mudanças legais e culturais fizeram com que reclamações, queixas e processos por parte das vítimas se tornassem mais fáceis do que antes nos quatro países.

12) Embora, em termos gerais, as noções de beleza tradicionalmente celebrem o cabelo louro e os olhos azuis, geralmente associados à classe e ao status, quando o prazer e o amor estão em jogo, e estes estão se tornando exigências cada vez mais populares na escolha de um parceiro, as noções de beleza variam bastante - e tendem a ser mais morenas. Mesmo que estas mudanças ainda não tenham sido reconhecidas em concursos nacionais de beleza, elas passaram a ser percebidas nas imagens associadas à cultura jovem e à música popular, e ainda mais nos resultados de várias pesquisas sobre juventude e sexualidade.

13) Noções de prazer sexual e sexualidade são, no geral, componentes importantes da conceituação diária e intelectual de 'raça'. Então, idéias sobre prazer sexual e o 'outro' racial podem confirmar ou subverter o domínio e a hierarquia racial. Afinal, (a busca de) prazer sexual também é um momento na vida onde experiências ('fantasias') são vivenciadas e onde as pessoas sentem que a sua individualidade passa pelo teste mais importante.

14) Uma boa parte da identidade étnica é, no fundo, identidade de gênero. Em muitos aspectos, o gênero é a lente através da qual a identidade étnica é vivenciada. Certas etnicidades e racializações correspondem a um uso específico do corpo, muitas vezes à transmissão de imagens associadas à sexualidade. Nestas imagens, por exemplo, o homem negro surge como forte e amea- 
çador ou fraco e sem poder, e a mulher negra como forte e uterina ou sensual e dada ao senhor (branco). Em se falando de representações em torno da sexualidade nas populações definidas como negras, existe uma tendência a haver pouco espaço para qualquer tipo de 'normalidade' (a família nuclear com mãe, pai e dois filhos), assim como para combinações complexas ou intermediárias (comportamentos sexuais não-centrados no hiperenfatizar do par masculinidade/feminilidade). Estas imagens, é claro, são o produto de relações específicas de raça e gênero que, durante a época passada, começaram a mudar. Em outras palavras, estas tendências nas relações de gênero levarão à mudança nas construções da negritude ligadas a gênero.

15) A linguagem corporal e as imagens/discursos sobre sensualidade fazem parte da construção da brancura e negritude nos quatro países, apesar das diferenças demográficas entre eles. E, cada vez mais, a cultura e a identidade negra - e, até certo ponto, as identidades e culturas indígenas nativas - são sustentadas por princípios estéticos vivenciados e expressados no domínio público do lazer e em uma interação estreita com a cultura jovem e a indústria do lazer. Isto explica a alta incidência da internacionalização de vários ícones negros em países diferentes - um bom exemplo é a lanchonete onde fiz muitas das entrevistas em grupo em Aguablanca, chamada Sabor hip hop.

Pode-se dizer certamente que a percepção e a experiência da saúde reprodutiva são mediadas pela classe, geração e, freqüentemente, posição étnica. A experiência de identidade étnica e a de saúde reprodutiva estão passando por uma mudança total. Esta mudança ainda não é tratada nas pesquisas nem nas intervenções sociais.

A transformação da intimidade, muitas vezes considerada como um dos produtos principais da modernidade, está tendo efeitos diferenciais. Em vez de apenas fomentar uma única nova condição em termos da experiência geral da sexualidade, do amor romântico e das práticas corporais, parece estar levando a uma renovada fragmentação e diversidade na nossa forma de amar e de vivenciar o corpo e o sexo. Ou entendemos como estes processos funcionam detalhadamente, ou não seremos capazes de apresentar a nossa intervenção em uma linguagem e através de metodologias que estejam em sintonia com a vida cotidiana - isto é sempre relevante, mas talvez seja ainda mais quando lidamos com coisas tão íntimas quanto o corpo, o sangue e o sexo.

As pesquisas sobre práticas sexuais, vida doméstica, discursos e negociações no que diz respeito a papéis de gênero podem ajudar a compreender o que muda, o que permanece relativamente localizado e os tipos de práticas e morais que se tornam mais genuinamente universais. 
Nos quatro países em questão, não existe um reconhecimento do campo da problemática e das possíveis intervenções ditas de 'saúde reprodutiva e juventude negra'. Na verdade, este é um campo de pesquisa e de futuras intervenções sociais quase que inteiramente a ser desenvolvido. Isto é importante porque a sexualidade e a etnicidade são geralmente construídas uma em relação à outra. No entanto, é preciso ter cuidado para não se contribuir ainda mais com a naturalização das 'diferenças' raciais e sexuais. O que comumente é visto como específico no comportamento e na cultura sobre a sexualidade dos jovens negros, geralmente foi construído externamente, como parte de uma agenda moral - e moralista - que atribuiu um papel determinado à corporalidade, vida familiar e experiência sexual entre os negros.

$\mathrm{Na}$ maioria das organizações e dos grupos de ação sobre saúde sexual que visitei, a questão da etnicidade não é abordada. E quando é, isto não é feito com o mesmo cuidado que se tem com diferenças de geração e de classe que são de fato duas variáveis fundamentais que influenciam o estilo e a linguagem do trabalho social. Quando a etnicidade é abordada, isto se dá através da aplicação de noções estáticas de comunidade e cultura. Geralmente, diz respeito a um chamado para se retornar às tradições. Isto está muito longe do uso criativo, feito pela maioria dos jovens em questão, de traços associados à cultura dos seus pais, assim como ao passado em geral como marcadores étnicos. Estamos diante de uma contradição porque, embora uma parcela crescente da insatisfação com o status quo seja agora verbalizada e expressa em termos étnicos, principalmente entre os jovens, esta insatisfação muitas vezes resulta do sentimento de exclusão do acesso à modernidade e ao consumo - eles não querem voltar ao 'passado étnico'.

Em resumo, as relações entre saúde reprodutiva e 'raça' ou etnicidade não estão sendo abordadas em toda a sua riqueza e complexidade. A inspiração deve ser tirada de um grande número de fontes e campos de intervenção - ou seja, estudos sobre a masculinidade, estudos étnicos e raciais, estudos sobre a juventude, estudos sobre a violência, a criminalidade e o uso de drogas.

Uma perspectiva regional não é apenas útil, já que estes países apresentam tantas semelhanças, mas também fortalecedora, porque as pessoas ativas nestas áreas na América Latina podem adquirir autoconfiança e se tornar menos pessimistas em relação aos recursos locais, ao perceberem que contextos diferentes na região podem servir de aprendizado. Ao criar-se uma rede regional com capacidade de treinamento, pode-se então se relacionar com o filão principal dos estudos sobre saúde reprodutiva - esmagadoramente concentrados no Hemisfério Norte - , a partir de uma posição mais forte e produtiva. 


\section{Referências bibliográficas}

BARTOLOMÉ, M. \& BARABAS, A. (Eds.) Autonomías Étnicas y Estados Nacionales. Ciudad de México: Conaculta, 1998.

BELTRÁN, G. A. Cujila: esbozo etnográfico de un pueblo negro. Ciudad de México: Fundo Economico de Cultura, 1956.

CIDCA/DEVELOPMENT STUDY UNIT. Ethnic Groups and the Nation State: the case of the Atlantic coast in Nicaragua. Estocolmo: Dept. de Antropologia Social, Universidade de Estocolmo, 1987.

FRAZIER, F. 1942. The negro family in Bahia, Brasil. American Sociological Review, 4(7):465-478, 1942.

GORDON, E. Disparate Diasporas: identity and politics in an African-Nicaraguan community. Austin: University of Texas Press, 1999.

HARVEY, N. La Rebelión de Chiapas: la lucha por la tierra y la democracia. Ciudad de México: Ediciones ERA, 2000.

HEGG ORTEGA, $\mathrm{M}$. El régimen de autonomia en Nicarágua: contradicciones históricas y debates recientes. Alteridades, 7(14):99-105, 1997.

HERSKOVITS, M. The Myth of the Negro Past. Nova York: Harper \& Bros., 1941.

HERSKOVITS, M. The negro in Bahia, Brazil: a problem in method. American Sociological Review, 8(VII):394-404, 1943.

MACHADO, W. Diagnóstico socioeconómico de la juventud en Bluefields. Bluefields: CIDCA/URACCAN, 1998.

MINORITY RIGHTS GROUP. Afro-Latin Americans Today: no longer invisible. Londres: Minority Rights Publications, 1995.

MINORITY RIGHTS GROUP. Afro-Central Americans: rediscovering the African Heritage. Londres: Minority Rights Publications, 1996.

MOSQUERA, C. \& MERCADO, E. Pandillas juveniles en sectores populares de Cartagena, 1989. Trabalho de colação de grau, Cartagena: Faculdade de Serviço Social, Universidade de Cartagena.

NASCIMENTO, A. do. O Genocídio do Negro Brasileiro: processo de um racismo mascarado. Rio de Janeiro: Paz e Terra, 1978.

PÉREZ RUIZ, M. L. Los pueblos indígenas y las paradojas del censo de 1990. Antropología, 41:66-79, 1994.

PINTO, E. Aborto numa perspectiva étnica e de gênero: um olhar masculino. In: ARILHA, M. (Org.) Homens e Masculinidades. São Paulo: Editora 34, 1998.

QUINTIN QUILEZ, P. Relaciones interraciales, sociabilidades masculinas juveniles y segregación laboral de la poblacion afrocolombiana en Cali. Documentos de Trabajo 49, CIDSE, Universidad del Valle, Cáli, 2000. 
URREA, F. Ser hombre negro y joven: construcción de identidades masculinas entre sectores populares excluidos en Cali (Colombia). Trabalho apresentando no VII Colóquio Nacional de Sociologia, Universidad del Valle, Cáli, mayo 3-5, 2000a.

URREA, F. Construcción de redes familiares entre migrantes de la costa pacífica y sus descendentes en Cáli. Documento de Trabajo 48, CIDSE, Universidad del Valle, Cali, $2000 \mathrm{~b}$.

VIVEROS VIGOYA, M. Dionisios negros: sexualidad, corporalidad y orden racial en Colombia. Trabalho apresentado na Conferência Internacional sobre Raça, Classe e Gênero, Salvador, abril, 2000.

WADE, P. Music, Race and Nation: musica tropical in Colombia, Chicago: Chicago University Press, 2000.

WERNECK, I.; MENDONÇA, M. \& WHITE, E. (Orgs.) O Livro da Saúde das Mulheres Negras. Rio de Janeiro: Pallas/Criola, 2000.

WHITTEN, N. \& TORRES, A. (Eds.) To Forge the Future in the Fires of the Past: blackness in Latin America and the Caribbean. Nova York: Carlson Publishing, 1995. 